\title{
Fishery, population characteristics and stock status of the bigeye thresher Alopias superciliosus Lowe, 1841 off Thoothukudi, south-east coast of India
}

\author{
P. P. MANOJKUMAR, L. RANJITH, K. KARUPPASAMY* AND K. P. KANTHAN \\ Tuticorin Regional Station of ICAR-Central Marine Fisheries Research Institute, Thoothukudi - 628 001, Tamil Nadu, India \\ ${ }^{*}$ College of Fisheries Nautical Technology, Tamil Nadu Dr. J. Jayalalithaa Fisheries University, Thoothukudi - 628001 \\ Tamil Nadu, India \\ e-mail:manojppin@yahoo.com
}

\begin{abstract}
Fishery, population parameters and stock estimates of the bigeye thresher Alopias superciliosus Lowe, 1841 from the Thoothukudi coast of Gulf of Mannar Marine Biosphere Reserve (GoMMBR) was studied during the period 2015 to 2019. Results of the study reveals that the estimated annual average production of sharks from Thoothukudi region was 105 $\mathrm{t}$ of which the dominant shark species was A. supercilious (52.70\%). The length of the sampled A. supercilious ranged between 108 and $265 \mathrm{~cm}$. Results of the length-weight relationship showed negative allometric growth with $\mathrm{b}$ value of 2.66. The growth parameters $v i z$, asymptotic length $\left(\mathrm{L}_{\infty}\right)$, growth co-efficient $(\mathrm{K})$ and arbitrary origin of growth $\left(\mathrm{t}_{0}\right)$ were estimated at $367 \mathrm{~cm}, 0.39 \mathrm{y}^{-1}$ and 0.12 respectively. The mortality parameters viz, total mortality (Z), fishing mortality (F) and natural mortality (M) rates were estimated at $1.20,0.70$ and $0.50 \mathrm{y}^{-1}$, respectively. In Thoothukudi, the recruitment season of A. superciliosus was found during March and October showing optimal exploitation with exploitation rate (E) of 0.58 and the estimated exploitation ratio (U) was 0.54 . The virtual population analysis (VPA) showed a fishing pressure on the 240 to $320 \mathrm{~cm}$ length group. The estimated annual catch and maximum sustainable yield (MSY) were 58 and $68 \mathrm{t}$ respectively. The present study gives valuable baseline information on the fishery and population characteristics of this vulnerable and data deficit resource $A$. superciliosus off Thoothukudi.
\end{abstract}

Keywords: Growth and mortality parameters, Maximum sustainable yield, Recruitment overfishing, Virtual population analysis

\section{Introduction}

Thresher sharks are large lamniformes sharks belonging to the genus Alopias (Family: Alopiidae). These are extensive, migratory sharks with overlapping distribution from low shore waters to the high seas which are found in the temperate and tropical oceans of the world (Compagno, 2001). The family comprises three valid species viz, common thresher Alopias vulpinus (Bonnaterre, 1788), bigeye thresher A. superciliosus Lowe, 1841 and pelagic thresher $A$. pelagicus Nakamura, 1935 (Gruber and Compagno, 1981; Compagno, 1984). All the three species are listed as 'vulnerable' as per the International Union for Conservation of Nature (IUCN) in the Red List of Threatened Species and globally there is a continued decline in their populations (Amorim et al., 2009). The bigeye threshers are reported around the world; commonly distributed in the Indo-Pacific region, usually at low latitude and are considered relatively rare with local abundance in certain areas (Gubanov and dan Paramonov, 1993). Bigeye thresher exhibits slow growth with an estimated age at maturity of 12-13 years and fecundity is usually two pups per litter (Chen et al.,
1997). Globally, the information on their biology, ecology, habitat and the landed catches of $A$. superciliosus was under-reported and limited (Chen et al., 1997). The Food and Agriculture Organisation of the United Nations (FAO) states that these species are considered fully exploited or overexploited globally (Maguire et al., 2016). The ecological risk assessments in terms of vulnerability to overfishing by the International Commission for Conservation of Atlantic Tunas (ICCAT) and the Indian Ocean Tuna Commission (IOTC) indicated that the bigeye threshers ranked second among 17 Indian Ocean elasmobranch species and first among 16 Atlantic species (ICCAT, 2009; Murua et al., 2018).

The sharks of the Indian Ocean region are considered overexploited based on the recent review of fisheries of this region (Yang et al., 2005). The information on the thresher sharks is mainly from the large meshed gillnet fisheries operating off Indian and Sri Lankan coasts which includes other shark landings since the 1980s (Ross, 1999). In the Atlantic Ocean, this species has to be discarded in the sea as capture is prohibited and therefore trends in the landings data are largely lacking (Young et al., 2016). 
In addition, carcass removal especially in offshore and high seas fisheries has been reported from the Indian Ocean region (Anderson and Simpfendorfer, 2005). In India, the reports on occurrence of Alopias species from mechanised drift gillnetters operating from Thoothukudi coast was documented for A. pelagicus (Ranjith et al., 2014b) and A. superciliosus (Gouthaman et al., 2014). Globally, studies on the age and growth of $A$. superciliosus was reported by a few authors (Liu et al., 1998; Cortes et al., 2010; Tsai et al., 2010; Cao et al., 2011; Fernandez-Carvalho et al., 2011) and there are no reports from the Indian waters. In addition, no information is available on the population dynamics and stock assessment of $A$. superciliosus. Hence, the present study was undertaken to assess the population characteristics and stock stauts of $A$. superciliosus and to find out the extent of fishing pressure on this resource exploited along the Thoothukudi coast, in southern India.

\section{Materials and methods}

The data on the catch and effort of sharks for a period of five years from 2015 to 2019 from different fishing gears operating along the Thoothukudi region (Fig. 1), collected by the Fisheries Resource Assessment Division (FRAD), ICAR-Central Marine Fisheries Research Institute (ICAR-CMFRI), India was used for this study. The total length (TL) to the nearest $0.1 \mathrm{~cm}$ and individual weight (W) was measured to the nearest gram following the method described by Compagno (1984). The length-weight

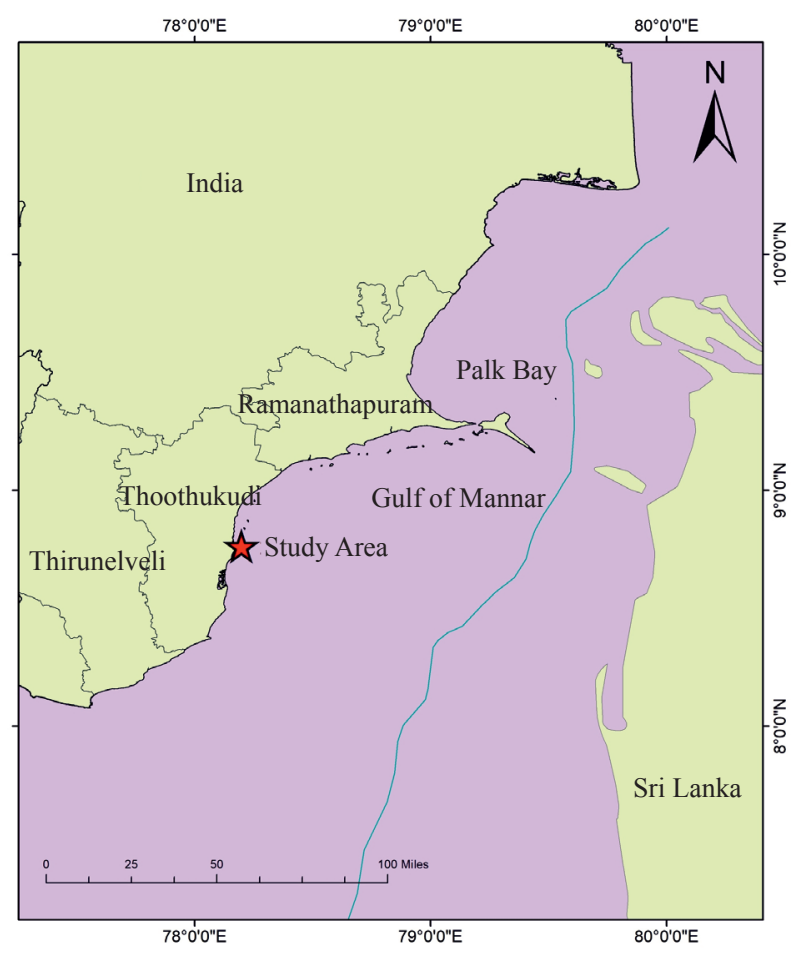

Fig. 1. Map showing the location of study area relationship was studied following the method described by Le Cren (1951). The length-frequency distribution data of $A$. superciliosus comprising 1,675 specimens collected from Thoothukudi, through random sampling technique on a weekly basis was used for estimating the age, growth and mortality parameters and further for stock assessment studies. For the growth studies, the length data was grouped into $5 \mathrm{~cm}$ class intervals and the raised monthly frequency distribution was calculated following Sekharan (1962). FiSAT II program was utilised for assessing the age and growth (Gayanilo et al., 2005). Asymptotic length $\left(\mathrm{L}_{\infty}\right)$, growth curvature $(\mathrm{K})$ and arbitrary origin of growth $\left(\mathrm{t}_{0}\right)$ values were investigated by non-parametric scoring of von Bertalanffy growth function (VBGF) fit utilising ELEFAN-1 for the time frame January 2015 to December 2019. Length converted catch curve method was used for estimating the instantaneous total mortality rate (Z) (Pauly, 1983). Natural mortality (M) was assessed by Pauly's equation considering $28^{\circ} \mathrm{C}$ as the mean yearly temperature (Pauly, 1984). Coefficient of fishing mortality (F) was determined utilising the relationship $\mathrm{Z}=\mathrm{F}+\mathrm{M}$. Length structured virtual population analysis (VPA) was used to find out the size of each length group. Recruitment pulses were analysed from the length frequency data. Total stock $(\mathrm{Y} / \mathrm{U})$ and annual stock $(\mathrm{Y} / \mathrm{F})$ were estimated using annual catch (Y), where $\mathrm{Y}$ is yield, $\mathrm{U}$ is exploitation ratio and $\mathrm{F}$ is fishing mortality. Exploitation rate (E) was estimated as $E=F / Z$ and exploitation ratio (U) was estimated using the equation $\mathrm{U}=\mathrm{F} / \mathrm{Z}\left(1-\mathrm{e}^{-\mathrm{z}}\right)$ (Sparre and Venema, 1992). Maximum sustainable yield (MSY) was estimated as per Gulland (1956). Yield isopleth diagrams of $A$. superciliosus were derived by FiSAT using $\mathrm{L}_{50} / \mathrm{L}_{\infty}$ and $\mathrm{F} / \mathrm{Z}$ values.

\section{Results and discussion}

\section{Fishery of sharks}

In the Gulf of Mannar Marine Biosphere Reserve (GoMMBR) region of Tamil Nadu, sharks are a non-targeted fishery whereas they are caught by non-mechanised and mechanised crafts as a bycatch in fishing gears like trawls, hook and lines and gillnets. In Thoothukudi region of GoMMBR, the major chunk of the Alopias species are caught mainly in the large meshed drift gillnets (locally known as Paruvalai) and hook and line (Kannan et al., 2013, Sivadas et al., 2013, Ranjith et al., 2014a). In recent years, Tharuvaikulam, Threspuram and Punnakayal coastal villages of Thoothukudi have emerged as the most important shark landing centres where sharks are landed occasionally as bycatch along with scombrids and large pelagics. In addition, fishermen from Kombuthurai fishing village of Thoothukudi, who are the migrant fishermen from Kanyakumari target sharks by hook and line fishing but very recently due to lack of 
catch they shifted the target to pelagics like carangids, seer fishes, barracudas and other large pelagics.

Shark fishery along the study region does not form any pattern and shows wide variation in the landings. The highest landing of sharks was recorded in 2016 at 219 t with an average of $123 \mathrm{t}$; after which the fishery showed a declining trend (Fig. 2). Manojkumar et al. (2019) observed that though sharks occur in small quantities in the entire marine fish landings off Thoothukudi coast, bigeye thresher support an important fishery from the region.

The catch rate of sharks ranged from 0.10 to $0.49 \mathrm{~kg}$ unit $^{-1}$ with an average of $0.79 \mathrm{~kg}$ unit $^{-1}$ during the study period. The catch rate of sharks in gillnet units ranged between $0.09 \mathrm{~kg}$ unit $^{-1}$ (2018) and $0.72 \mathrm{~kg} \mathrm{unit}^{-1}$ (2016) whereas in hook and line units it ranged between $0.09 \mathrm{~kg}$ unit $^{-1}$ (2016) and $0.28 \mathrm{~kg} \mathrm{unit}^{-1}$ (2017), with an average of $0.18 \mathrm{~kg} \mathrm{unit}^{-1}$. In trawl, the catch rate fluctuated between $0.07 \mathrm{~kg} \mathrm{~h}^{-1}$ (2018) and $0.09 \mathrm{~kg} \mathrm{~h}^{-1}$ (2016) with an average of $0.08 \mathrm{~kg} \mathrm{~h}^{-1}$ (Fig. 3).

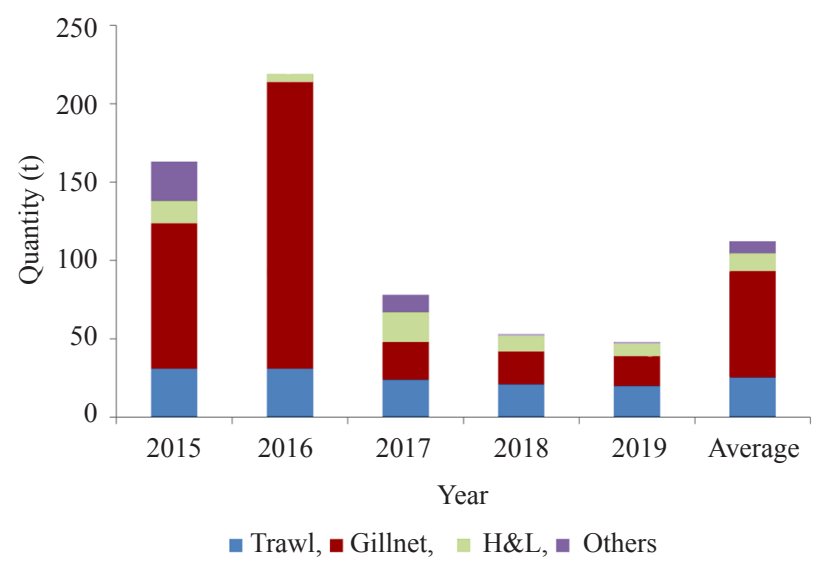

Fig. 2. Quantity of sharks landed at Thoothukudi

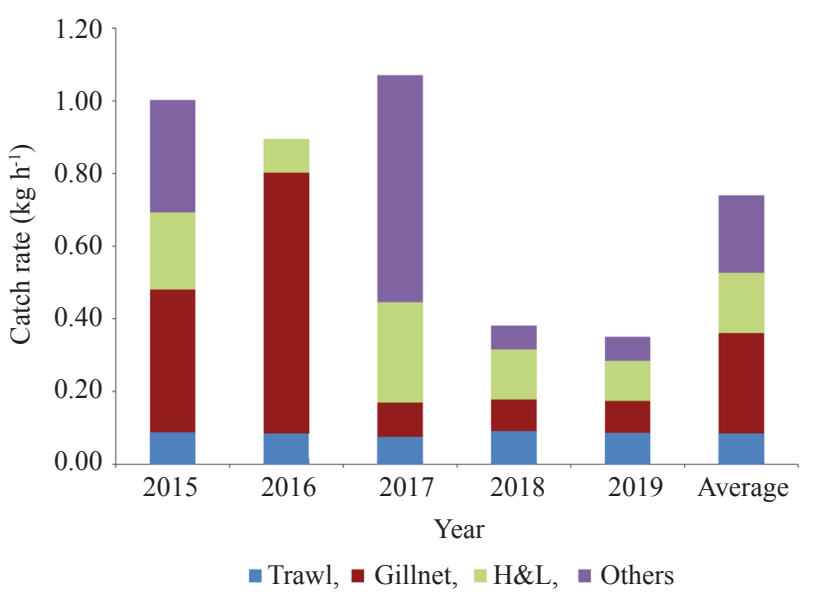

Fig. 3. Catch rate of sharks at Thoothukudi

\section{Species composition}

The Gulf of Mannar is rich in elasmobranch diversity and elasmobranchs are being regularly exploited in this region (Raje et al., 2007). Eleven species of sharks were recorded during the study period, whereas along the coast of Tamil Nadu and Kerala coasts about 30 to 40 species of sharks belonging to 15 genera occurs and only very few occur in the commercial fishery (Kasim, 1991). Raje et al. (2007) reported 110 elasmobranch species belonging to 42 genera which include 66 species of sharks, 8 species of guitar fishes, 4 species of sawfishes and 32 species of rays from Indian waters. During the present study, A. superciliosus dominated the catch forming more than $52.71 \%$ of shark landings and the other species contributing to the shark landings were Chiloscyllium griseum $(8.03 \%)$, C. indicum $(7.87 \%)$, Carcharhinus melanopterus (6.77\%), C. brevipinna (6.02\%), C. sorrah (4.61\%), Loxodon macrorhinus (4.46\%), Scoliodon laticaudus (3.41), Rhizoprionodon acutus (3.34\%) and A. pelagicus $(2.70 \%)$, but their landings were too meagre (Fig. 4). Among the thresher sharks, A. superciliosus form a good fishery in Thoothukudi region throughout the year. Hanfee (1999) revealed that shark fishery is multispecies in nature and no species dominates in other states of India. In an earlier study from Thoothukudi coast, shark fishery was mainly supported by families of Carcharhinidae, Echinorhinidae, Hemiscyllidae, Alopidae, Sphyrnidae and Squalidae wherein the family Carcharhinidae alone represented $45.1 \%$ of shark catch and family Hemiscyllidae represented $30.6 \%$ of shark catch (Abdussamad et al., 2006). The present study reports the dominance of bigeye thresher, $A$. superciliosus that has been caught by the drift-gillnets operated along the Thoothukudi region. Landings of thresher sharks was reported from Thoothukudi waters of Gulf of Mannar (Gowthaman et al., 2014; Ranjith et al., 2014b). Sudarsan et al. (1988) identified the existence of pelagic sharks in the potentially rich fishing grounds along the Gulf of

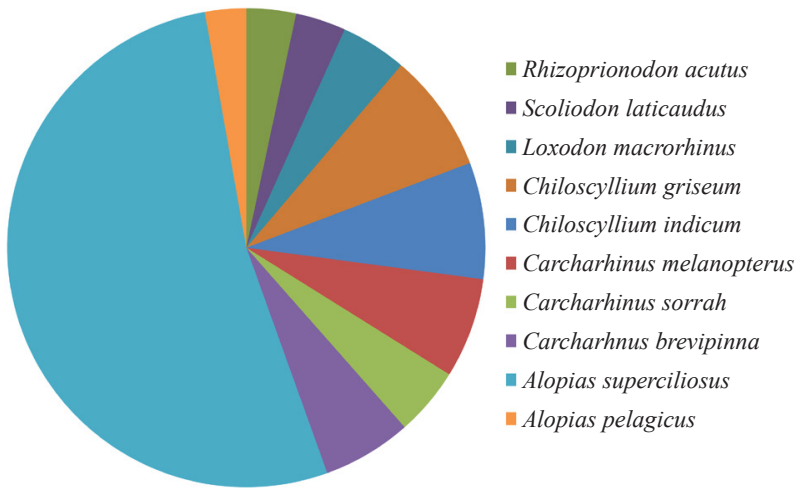

Fig. 4. Species composition of sharks landed and Thoothukudi 
Mannar, Tamil Nadu. Manojkumar et al. (2019) observed that increase in landings or shift in biomass of pelagic sharks was mainly by the landing of bigeye thresher shark A. superciliosus along the Thoothukudi region.

\section{Length-weight relationship}

The length-weight relationships of $A$. superciliosus were derived based on analysis of 285 males in the range of $110-265 \mathrm{~cm}(8.2-126 \mathrm{~kg})$ and 208 females in the range of $108-238.2 \mathrm{~cm}(12.5-78.5 \mathrm{~kg})$. The relationships were derived by the least square method and the regression equations obtained for males and females are:

Female: $\mathrm{W}=0.000100058 \mathrm{~L}^{2.5140}(\mathrm{r}=0.9614)$

Male: $\mathrm{W}=0.00001972 \mathrm{~L}^{2.8140}(\mathrm{r}=0.9564)$

The analysis of covariance showed that there was no significant difference at 5\% level between sexes and the equation derived for pooled sexes as:

$$
\mathrm{W}=0.000069745 \mathrm{~L}^{2.6630}(\mathrm{r}=0.9651)
$$

Age, growth and mortality parameters

The study reveals presence of multiple modes in the monthly length frequency data whereas traceable modes for two consecutive months were used to assess the growth of cohorts from 2015 to 2019 (pooled data) of A. superciliosus (Fig. 5). The estimated growth parameters of A. superciliosus are shown in Table 1. Asymptotic lengths $\left(\mathrm{L}_{\infty}\right)$ and growth coefficient $(\mathrm{K})$, were $367 \mathrm{~cm}$ and 0.39 respectively. The estimated maximum lifespan was found to be 21.5 years. The von Bertalanffy's growth function (VBGF) plot is represented in Fig. 4. FernandezCarvalho et al. (2011) got higher values from North-east tropical Atlantic and the estimated growth parameters from length data of $A$. superciliosus were, $\mathrm{L}_{\infty}=206 \mathrm{~cm}$ (male); $293 \mathrm{~cm}$ (female) and $\mathrm{K}=0.18$ (male) and 0.60 year $^{-1}$ (female). Factors explaining the relationship between natural mortality coefficient and growth coefficient
$(\mathrm{M} / \mathrm{K})$ was 1.28 which is well within the normal range of 1 to 2.5, as suggested by Beverton and Holt (1959). The generalised VBGF growth equation for $A$. superciliosus and mortality parameters and exploitation rate are shown in Table 1. Life span of this species was estimated as 21 years. Average natural mortality $(\mathrm{M})$ was found to be $0.50 \mathrm{y}^{-1}$ and average fishing mortality coefficient (F) was $0.70 \mathrm{y}^{-1}$. Estimated exploitation rate $(\mathrm{E})$ was 0.58 Estimated ' $Z$ ' value by length converted catch curve method was 1.20 as shown in Table 2. Since, the natural mortality rate of this species is high, fishing mortality may have severe consequences for their populations (Dulvy et al., 2008), with declines occurring even at relatively low levels of fishing mortality (Stevens et al., 2000). It could be inferred that fishing mortality was higher compared to natural mortality and the same trend was evident in Atlantic waters (Dulvy et al., 2008). A comparison indicating the von Bertalanffy growth (VBGF) parameters from studies carried out worldwide for A. superciliosus is given in Table 3.

Table 1. Growth, mortality and population parameters of A. superciliosus exploited off Gulf of Mannar, southeast coast of India

\begin{tabular}{ll}
\hline Population parameters & Values \\
\hline Asymptotic length $\left(\mathrm{L}_{\infty}, \mathrm{cm}\right)$ & 367 \\
Growth coefficient $\left(\mathrm{K}\right.$ year $\left.^{-1}\right)$ & 0.39 \\
Arbitrary origin of growth $\left(\mathrm{t}_{0}\right)$ & 0.12 \\
Growth coefficient $(\mathrm{M} / \mathrm{K})$ & 1.28 \\
Annual total mortality rate $(\mathrm{Z})$ & 1.20 \\
Annual fishing mortality rate $(\mathrm{F})$ & 0.70 \\
Annual natural mortality rate $(\mathrm{M})$ & 0.50 \\
Length at first capture $\left(\mathrm{L}_{\mathrm{C}}, \mathrm{cm}\right)$ & 120 \\
Annual exploitation rate $(\mathrm{E})$ & 0.58 \\
$\mathrm{E}_{50}$ & 0.28 \\
$\mathrm{E}_{\max }$ & 0.54 \\
\hline
\end{tabular}

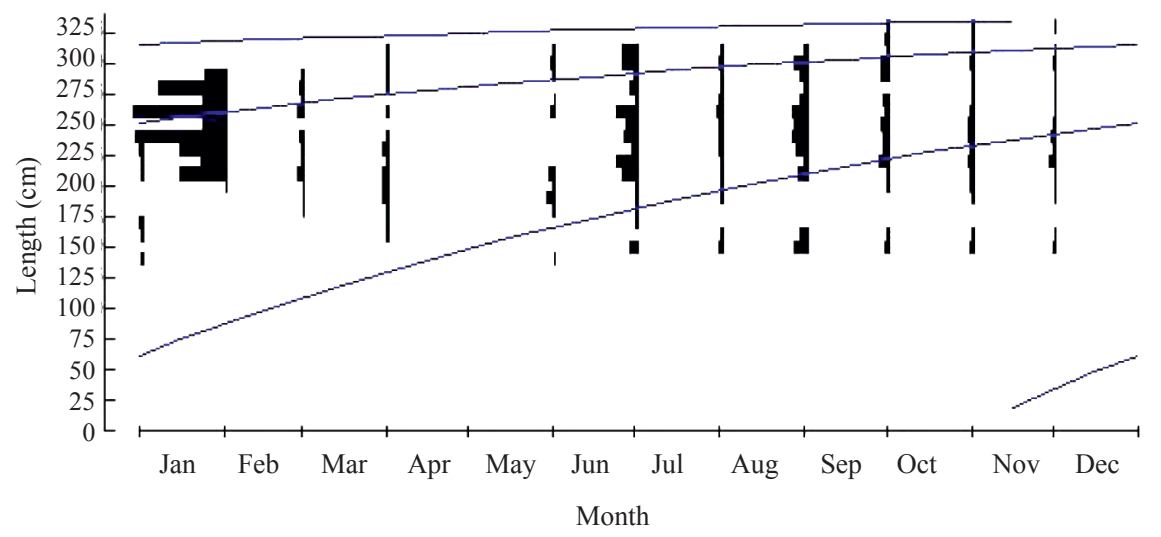

Fig. 5. Plot of FiSAT analysis of $A$. superciliosus exploited off Thoothukudi 
Table 2. Mortality parameters and exploitation rate of A. superciliosus off Thoothukudi coast

\begin{tabular}{lllll}
\hline Year & $\mathrm{F}$ & $\mathrm{M}$ & $\mathrm{Z}$ & $\mathrm{E}=\mathrm{F} / \mathrm{Z}$ \\
\hline 2015 & 0.7 & 0.49 & 1.19 & 0.59 \\
2016 & 0.8 & 0.52 & 1.32 & 0.61 \\
2017 & 0.6 & 0.48 & 1.08 & 0.56 \\
2018 & 0.7 & 0.5 & 1.20 & 0.58 \\
2019 & 0.71 & 0.50 & 1.18 & 0.60 \\
Average & 0.70 & 0.50 & 1.20 & 0.60 \\
\hline
\end{tabular}

Recruitment pattern, virtual population analysis and yield per recruit

The recruitment pattern of $A$. superciliosus showed a distinct peak with maximum recruitment during February to April contributing to $46 \%$ of total recruitment (Fig. 6). Highest recruitment took place in March (18\%) and the lowest in July (4\%). In equatorial Pacific coast, A. pelagicus was recruited with a peak during April to July (Romero-Caicedo et al., 2014), However, in the present study, one major peak was observed from February to April in Thoothukudi coast of Gulf of Mannar. The major recruitment season coincides with the coastal monsoon ban in the south-east coast of India. The results of the length structured VPA employed to recognise the level of mortality on various length groups of $A$. superciliosus are shown in Fig. 7. Fishing pressure on A. superciliosus was found more in the length group of 240 to $320 \mathrm{~cm}$. Liu et al. (1998) and Tsai et al. (2010) assessed the stock status of the pelagic thresher shark in the waters off eastern Taiwan and north-western Pacific using spawning-per recruit models and VPA and the results indicated that with heavy fishing, the stock stands overexploited. The annual catch and annual stock exploitation ratio estimated for A. superciliosus are presented in Table 4. MSY for A. superciliosus off Thoothukudi waters is estimated as $58 \mathrm{t}$. Tsai et al. (2010) revealed the total mortality in MSY increased due to fishing. The mean size of pelagic threshers in the commercial catch declined since 1994, showing a further warning sign that overfishing is occurring in north-western Pacific. The yield per recruit for A. superciliosus from Thoothukudi waters is shown in Fig. 8. The $\mathrm{L}_{c} / \mathrm{L}_{\infty}$ for the present exploitation ratio (0.54) of $A$. superciliosus is 0.00142 and it has been inferred that maximum sustainable yield can be possible keeping the exploitation rate and $\mathrm{L}_{\mathrm{c}} / \mathrm{L} \infty$ at 0.050 and 0.48 respectively.

Table 3. Comparison of age and growth parameters of A. superciliosus in studies carried out worldwide

\begin{tabular}{|c|c|c|c|c|c|c|c|c|}
\hline Sl. No. & Study & Sex & $\begin{array}{l}\text { Size range } \\
(\mathrm{TL}, \mathrm{cm})\end{array}$ & $\begin{array}{l}\text { Sample } \\
\text { size }(\mathrm{N})\end{array}$ & $\begin{array}{l}\text { VBGF parameters } \\
\left(\mathrm{L}_{\infty}\right) \mathrm{cm}\end{array}$ & $\mathrm{K}\left(\mathrm{y}^{-1}\right)$ & $\begin{array}{l}\text { Max observed } \\
\text { age (years) }\end{array}$ & Region \\
\hline 1. & Present study & Pooled & $105-362$ & 315 & 367 & 0.39 & 22 & Bay of Bengal \\
\hline \multirow[t]{2}{*}{2} & \multirow[t]{2}{*}{ Pescas (2014) } & Male & $94-260$ & 241 & 245.6 & 0.09 & 25 & \multirow[t]{2}{*}{ Atlantic } \\
\hline & & Female & $102-265$ & 258 & 284.2 & 0.06 & 25 & \\
\hline \multirow[b]{2}{*}{3.} & \multirow{2}{*}{$\begin{array}{l}\text { Fernandez-Carvalho } \\
\text { et al. (2011) }\end{array}$} & Male & $101-210$ & 42 & 206.0 & 0.18 & 17 & \multirow{2}{*}{$\begin{array}{l}\text { NE Tropical } \\
\text { Atlantic }\end{array}$} \\
\hline & & Female & $115-242$ & 73 & 293.0 & 0.06 & 22 & \\
\hline \multirow[b]{2}{*}{4.} & \multirow[t]{2}{*}{ Liu et al. (1998) } & Male & NA-213.5 & 214 & 235.5 & 0.09 & 20 & \multirow{2}{*}{$\begin{array}{l}\text { NW Pacific } \\
\text { (Taiwan) }\end{array}$} \\
\hline & & Female & NA-256.5 & 107 & 241.7 & 0.09 & 21 & \\
\hline
\end{tabular}

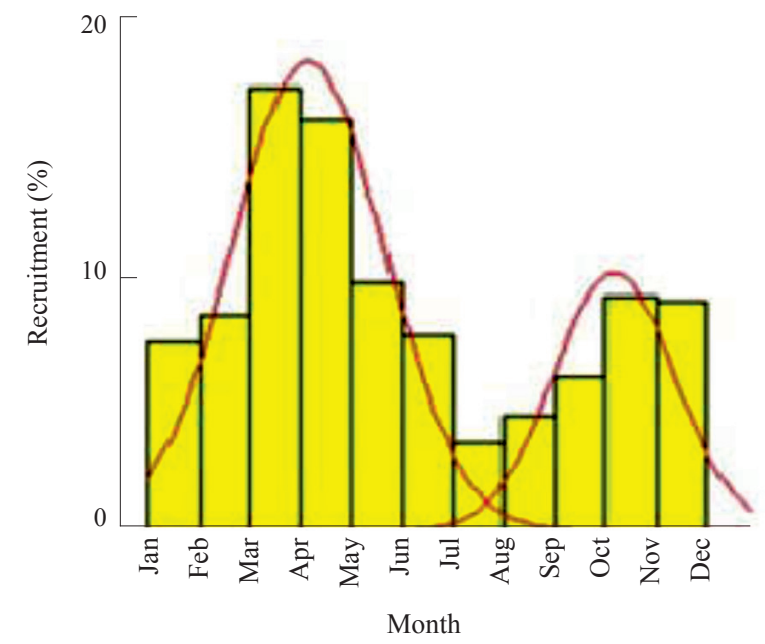

Fig. 6. Recruitment pattern of A. superciliosus exploited off Thoothukudi

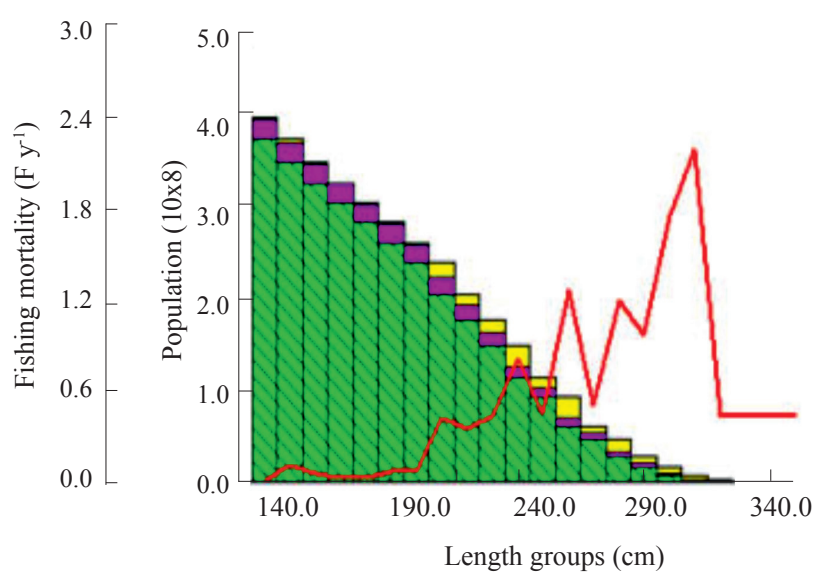

Fig. 7. Length structured virtual population analysis of A. superciliosus exploited off Thoothukudi 
Table 4. Exploitation ratio, total stock and annual stock of A. superciliosus off Thoothukudi coast

\begin{tabular}{lllll}
\hline Year & Annual catch $(\mathrm{t})$ & Exploitation ratio $(\mathrm{U})$ & Annual stock $(\mathrm{t})$ & Total stock $(\mathrm{t})$ \\
\hline 2015 & 53 & 0.54 & 76 & 98 \\
2016 & 97 & 0.53 & 121 & 183 \\
2017 & 50 & 0.53 & 84 & 94 \\
2018 & 71 & 0.53 & 102 & 133 \\
2019 & 68 & 0.53 & 98 & 128 \\
Average & 68 & 0.54 & 96 & 126 \\
\hline
\end{tabular}

The study also suggests that the fishing effort for $A$. superciliosus could be reduced by decreasing the number of boats or reducing the fishing duration to 3-4 h. The present study reveals that the stock of $A$. superciliosus is overexploited off Thoothukudi coast and there is a probability of depletion in the stock of this species in future.

India is a signatory to Convention on International Trade in Endangered Species of wild fauna and flora (CITES), the Convention on Migratory Species (CMS) wherein bigeye thresher shark, A. superciliosus is listed as 'Vulnerable' in the IUCN's Red List (Amorim et al., 2009) and comprehensive worldwide stock assessment wanting; in spite of lack of catch data. Moreover, in tune with the global concern in the population of bigeye thresher sharks, efforts have been initiated by ICAR-CMFRI to assess the status of the species in Indian waters. Further to this, ICAR-CMFRI has been recognised by CITES as the Scientific Authority for Non Detriment Findings (NDF) assessment of CITES listed species including A. superciliosus from Indian coast. In this contest, the present study provides valuable baseline information on the population characteristics and stock status of A. superciliosus along Thoothukudi coast of India for further management of the vulnerable species.

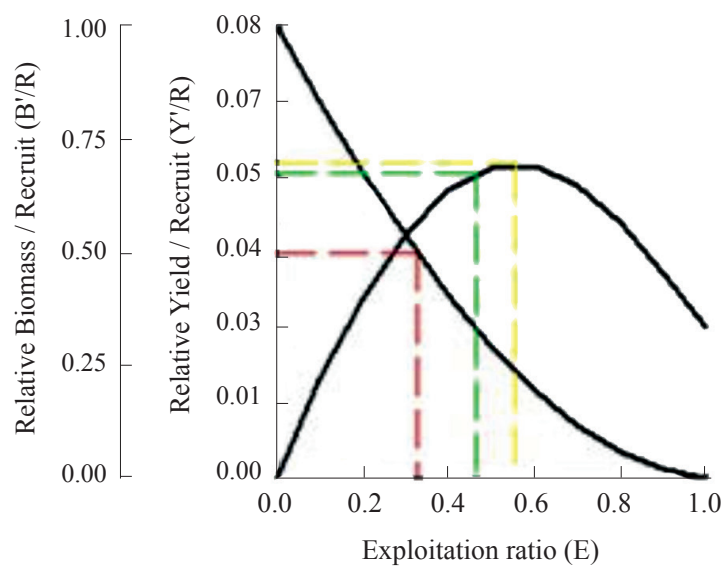

Fig. 8. Yield/Biomass recruitment of A. superciliosus exploited of Tuticorin

\section{Acknowledgements}

The authors are thankful to the Head, Demersal Fisheries Division and the Director, ICAR-CMFRI, Kochi, for their encouragement. The co-operation and help provided by the staff of Tuticorin Regional Station of ICAR-CMFRI is acknowledged with gratitude.

\section{References}

Abdussamad, E. M., Balasubramanian, T. S., Habeeb Mohammed, O. M. M J., Jayabalan, K., Arumugam, G., Sundararajan, D. and Manickaraja, M. 2006. Exploited marine fishery resources off Tuticorin along the Gulf of Mannar coast. Mar. Fish. Inf. Serv. T\&E Ser., 189: 1-9.

Amorim, A., Baum, J., Cailliet, G. M., Clo, S., Clarke, S. C., Fergusson, I., Gonzalez, M., Macias, D., Mancini, P., Mancusi, C., Myers, R., Reardon, M., Trejo, T., Vacchi, M. and Valenti, S. V. 2009. Alopias superciliosus. The IUCN Red List of Threatened Species 2009: e.T161696A5482468. https://www.iucnredlist.org/species/161696/894216.

Anderson, R. C. and Simpfendorfer, C. A. 2005. Regional overview: Indian Ocean. In: Fowler, S. L., Cavanagh, R. D., Merry Camhi, Burgess, G. H., Cailliet, G. M., Fordham, S. V., Simpfendorfer, C. A. and Musick, J. A. (Eds.), Sharks, rays and chimaeras: The status of the chondrichthyan fishes, Status survey. IUCN/SSC Shark Specialist Group, International Union for Conservation of Nature and Natural Resources (IUCN), Gland, Switzerland and Cambridge, UK, p. 140-149.

Beverton, R. J.H. and Holt, S. J. 1959. Areview of the lifespans and mortality rates of fish in nature and their relation to growth and other physiological characteristics. In: Wolstenholme, G. E. W. and Maeve O'Conner (Eds.), CIBA Foundation Symposium - The life span of animals (Colloquia on Ageing), vol. 5. Novartis Foundation Symposia Series, Novartis $(=\mathrm{CIBA}) \quad$ Foundation, Basel, Switzerland, p. 142-180. https://doi.org/10.1002/9780470715253.ch10.

Cao, D. M., Song, L. M., Zhang, Y., Lv, K. K. and Hu, Z. X. 2011. Environmental preferences of Alopias superciliosus and Alopias vulpinus in waters near Marshall Islands. N Z. J. Mar. Freshw. Res., 45(1): 103-119. https://doi.org/10.10 80/00288330.2010.540017

Chen, C. T., Liu, K. M. and Chang, Y. C. 1997. Reproductive biology of the bigeye thresher shark, Alopias superciliosus 
(Lowe, 1939) (Chondrichthyes: Alopiidae), in the northwestern Pacific. Ichthyol. Res., 44(3): 227-235.

Compagno, L. J. V. 1984. FAO Species catalogue, vol. 4. Sharks of the world: An annotated and illustrated catalogue of shark species known to date, part 2. Carcharhiniformes. FAO Fisheries Synopsis No. 125. Food and Agriculture Organisation of the United Nations, Rome, Italy, p. 251-655.

Compagno, L. J. V. 2001. Sharks of the world. An annotated and illustrated catalogue of shark species known to date, vol. 2 . Bullhead, mackerel and carpet sharks (Heterodontiformes, Lamniformes and Orectolobiformes). FAO Species catalogue for fishery purposes, No. 1, vol. 2. Food and Agriculture Organisation of the United Nations, Rome, Italy, $269 \mathrm{pp}$.

Cortes, E., Arocha, F., Beerkircher, L., Carvalho, F., Domingo, A., Heupel, M., Holtzhausen, H., Santos, M. N., Ribera, M. and Simpfendorfer, C. 2010. Ecological risk assessment of pelagic sharks caught in Atlantic pelagic longline fisheries. Aquat. Living Resour., 23(1): p. 25-34 DOI: https://doi. org/10.1051/alr/2009044.

Dulvy, N. K., Baum, J. K., Clarke, S., Compagno, L. J., Cortes, E., Domingo, A., Fordham, S., Fowler, S., Francis, M. P., Gibson, C. and Martinez, J. 2008. You can swim but you can't hide: The global status and conservation of oceanic pelagic sharks and rays. Aquat. Conserv. Mar. Freshw. Ecosystems, 18(5): 459-482. DOI: 10.1002/aqc.975.

Fernandez-Carvalho, J., Coelho, R., Erzini, K. and Santos, M. N. 2011. Age and growth of the bigeye thresher shark, Alopias superciliosus, from the pelagic longline fisheries in the tropical north-eastern Atlantic Ocean, determined by vertebral band counts. Aquat. Living Resour., 24: 359-368. https://doi.org/10.1051/alr/2011046.

Gowthaman, A. M., Jawahar, P. and Venkataramani, V. K. 2014. New Occurance of big eye tresher sharks, Alopias superciliosus, Lowe 1841 in Gulf of Mannar, south-east coast of India. Indian J. Geo-Mar. Sci., 43(5): 883-885.

Gayanilo, F. C., Sparre, P. and Pauly, D. 2005. FAO-ICLARM stock assessment tools II (FiSAT II). User's guide. FAO Computerised Information Series (Fisheries), No. 8. Food and Agriculture Organisation of the United Nations, Rome, Italy.

Gruber, S. H. and Compagno, L. J. V. 1981. Taxonomic status and biology of the bigeye thresher, Alopias superciliosus (Lowe, 1839). Fish. Bull. Natl. Mar. Fish. Serv., 79(4): 617-640.

Gubanov, E. P. and dan Paramonov, V. V. 1993. Oceanographical prerequisites for formation of concentration of large pelagic predator in the Indian Ocean. In: Yakovlev, V. N., Romanov, E. V., Lebedeva, N. A., Yak Tushy, Timokhin, I. G., Trotsenko, B. G. and Korkosh, V. V. (Eds), Resources of tuna and related species in the world ocean and problems of their rational utilisation, Yujiro, Kerch, Ukraine, p. 69-71.
Gulland, J. A. 1956. On the fishing effort in English demersal trawl fisheries. Fishery Invest. Lond. 2, 20(5): 41 pp.

Hanfee, F. 1999. Management of shark fisheries in two Indian coastal states: Tamil Nadu and Kerala. In: Shotton, R. (Ed.), Case studies of the management of elasmobranch fisheries. FAO Fisheries Technical Paper, No 378, part 1. Food and Agriculture Organisation of the United Nations, Rome, Italy, p. 316-338.

ICCAT 2009. Recommendation by ICCAT on the conservation of thresher sharks caught in association with fisheries in the ICCAT convention area. ICCAT Recommendation 2009-07. http://www.iccat.es/Documents/Recs/compendiopdfe/200907-e.pdf.

Kannan, K., Ranjith, L., Suresh Kumar, K., John James, K., Sathakathullah, S. M. and Madan, M. S. 2013. Occurrence of near threatened tiger shark, Galeocerdo cuvier (Peron and Lesueur, 1822) from Tuticorin coast, Tamil Nadu. Mar. Fish. Inf. Serv. T\&E Ser., 216: 13-14.

Kasim, M. H. 1991. Shark fishery of Veraval coast. J. Mar. Biol. Ass. India, 33(1\&2): 213-228.

Le-Cren, E. D. 1951. Length-weight relationship and seasonal cycle in gonad weight and condition in the perch (Perca fluviatilis) J. Anim. Ecol., 20: 201-219. http://dx.doi.org/ $10.2307 / 1540$.

Liu, K. M., Chiang P. J. and Chen C. T. 1998. Age and growth estimates of the bigeye thresher shark, Alopias superciliosus in north-eastern Taiwan waters. Fish. Bull., 96: 482- 491.

Maguire, M. G., Martin, D. F., Ying, G. S., Jaffe, G. J., Daniel, E., Grunwald, J. E., Toth, C. A., Ferris III, F. L. and Fine, S. L. and Comparison of age-related Macular Degeneration Treatments Trials (CATT) Research Group 2016. Five-year outcomes with anti-vascular endothelial growth factor treatment of neovascular age-related macular degeneration: The Comparison of Age-Related Macular Degeneration Treatments Trials. Ophthalmology, 123(8): 1751-1761. DOI: 10.1016/j.ophtha.2016.03.045.

Manojkumar, P. P., Ranjith, L. and Kanthan, K. P. 2019. Fishery and geospatial mapping of pelagic elasmobranchs from mechanised gillnetters of Tharuvaikulam, Tuticorin, south-east coast of India. Indian J. Fish., 66(1): 56-63.

Murua, H., Santiago, J., Coelho, R., Zudaire, I., Neves, C., Rosa, D., Semba, Y., Geng, Z., Bach, P., Arrizabalaga, H. and Baez, J. C. 2018. Updated Ecological Risk Assessment (ERA) for shark species caught in fisheries managed by the Indian Ocean Tuna Commission (IOTC). Indian Ocean Tuna Commission, Mahe, Seychelles.

Pauly, D. 1983. Some simple methods for the assessment of tropical fish stocks. FAO Fisheries Technical Paper No. 234. Food and Agriculture Organisation of the United Nations, Rome, Italy, 52 pp.

Pauly, D. 1984. Fish population dynamics in tropical waters: A manual for use with programmable calculators. ICLARM Stud. Rev., 8: 325 pp. 
Raje, S. G., Sivakami, S., Mohanraj, G., Manojkumar, P. P., Raju, A. and Joshi, K. K. 2007. Atlas on the elasmobranch fishery resources of India. CMFRI Special Publication, No. 95, ICAR-Central Marine Fisheires Research Institute, Kochi, India, $253 \mathrm{pp}$.

Ranjith, L., Kanthan, P., Radhakrishnan, K. and Murugan, K. 2014a. Whale shark landed along Tuticorin coast. Cadalmin, CMFRI Newsletter, No. 140: ICAR-Central Marine Fisheires Research Institute, Kochi, India, p. 12.

Ranjith, L., Sivadas, M., Kannan, K., Kanthan, K. P. and Madan, M. S. 2014b. Occurrence of pelagic thresher shark, Alopias pelagicus (Alopiidae: Laminiformes) from Tuticorin, Gulf of Mannar. Mar. Fish. Inf. Serv. T\&E Ser., 217: $25-26$.

Romero-Caicedo, A. F., Galvan-Magana, F. and Martinez-Ortiz, J. 2014. Reproduction of the pelagic thresher shark Alopias pelagicus in the equatorial Pacific. J. Mar. Biol. Ass. UK, 94(7): 1501-1507.

Ross, S. H. 1999. Case studies of the management of elasmobranch fisheries. FAO Fisheries Technical Paper, No. 378/2. Food and Agriculture Organisation of the United Nations, Rome, Italy, 479 pp.

Sekharan, K. V. 1962. On the oilsardine fishery of the Calicut area during the years 1955-56 to 1958-59. Indian J. Fish., 9(2): 679-700.

Sivadas, M., Ranjith, L., Sathakathullah, S. M., John James, K. and Suresh Kumar, K. 2013. Pregnant female spinner shark, Carcharhinus brevipinna (Muller and Henle, 1839) landed at Tharuvaikulam, Tuticorin. Mar. Fish. Inf. Serv. T\&E Ser., 215: 18-75.
Sparre, P. and Venema, S. G. 1992. Introduction to tropical fish stock assessment. Part 1, Manual. FAO Fisheries technical paper No. 306. Food and Agriculture Organisation of the United Nations, Rome, Italy.

Stevens, J. D., Bonfil, R., Dulvy, N. K. and Walker, P. A. 2000. The effects of fishing on sharks, rays, and chimaeras (chondrichthyans) and the implications for marine ecosystems. ICES J. Mar. Sci., 57(3): 476-494. DOI:10.1006/jmsc.2000.0724.

Sudarsan, D., Sivaprakasam, T. E., Somvanshi, V. S., John, M. E. and Nair, K. N. V. 1988. An appraisal of the marine fishery resources of the Indian Exclusive Economic Zone. Bull. Fish. Surv. India, 18: 85 pp.

Tsai, W. P., Liu, K. M. and Joung, S. J. 2010. Demographic analysis of the pelagic thresher shark, Alopias pelagicus, in the north-western Pacific using a stochastic stage-based model. Mar. Freshw. Res., 61(9): 1056-1066. https://doi. org/10.1071/MF09303.

Yang, W. S., Moon, D. Y., Kim, S. S. and Koh, J. R. 2005. Report on the bycatch from a Korean observer on the Korean tuna longliner in the Indian Ocean in 2004. National Fisheries Research and Development Institute, Busan, Republic of Korea.

Young, C. N., Carlson, J., Hutchinson, M., Kobayashi, D., McCandless, C., Miller, M. H., Teo, S. and Warren, T. 2016. Status review report: Common thresher shark (Alopias vulpinus) and bigeye thresher shark (Alopias superciliosus). Final Report to National Marine Fisheries Service, Office of Protected Resources, National Marine Fisheries Service, National Oceanic and Atmospheric Administration (NOAA), US Department of Commerce, USA, 199 pp. 